This is a self-archived version of an original article. This version may differ from the original in pagination and typographic details.

Author(s): $\begin{aligned} & \text { Bravin, Carlo; Badetti, Elena; Puttreddy, Rakesh; Pan, Fangfang; Rissanen, Kari; } \\ & \text { Licini, Giulia; Zonta, Cristiano }\end{aligned}$

Title: Binding Profiles of Self-Assembled Supramolecular Cages from ESI-MS Based Methodology

Year: 2018

Version: Accepted version (Final draft)

Copyright: @ 2018 Wiley-VCH Verlag GmbH \& Co. KGaA, Weinheim

Rights: In Copyright

Rights url: http://rightsstatements.org/page//nC/1.0/?language=en

Please cite the original version:

Bravin, C., Badetti, E., Puttreddy, R., Pan, F., Rissanen, K., Licini, G., \& Zonta, C. (2018). Binding Profiles of Self-Assembled Supramolecular Cages from ESI-MS Based Methodology. Chemistry: A European Journal, 24(12), 2936-2943. https://doi.org/10.1002/chem.201704725 


\title{
Binding Profiles of Self-Assembled Supramolecular Cages from ESI-MS Based Methodology
}

\author{
Carlo Bravin, ${ }^{[a]}$ Elena Badetti, ${ }^{[b]}$ Rakesh Puttreddy, ${ }^{[b]}$ Fangfang Pan, ${ }^{[b]}$ Kari Rissanen, ${ }^{[b]}$ Giulia Licini, ${ }^{[a]}$ \\ and Cristiano Zonta*[a]
}

\begin{abstract}
Confined molecular environments own peculiar characteristics that make their properties unique in the field of biological and chemical sciences. In recent years, the advancement of synthetic supramolecular capsules and cages have offered the possibility to interpret the principles behind their self-assembly and functions, leading to new molecular systems which display outstanding properties in molecular recognition and catalysis. Herein, we report a rapid method based on ESI-MS for the determination of binding profiles for linear saturated dicarboxylic acids within a series of different cages. These cages have been obtained through the selfassembly of modified tris(pyridylmethyl)amine (TPMA) complexes and different diamines have been chosen to vary their size and flexibility. This methodology has allowed to gather how small changes in the structure of the host and guest can contribute to the recognition events. Moreover, it has been possible to study molecular systems which contains paramagnetic metals that are not suitable for classical binding constant determination by ${ }^{1} \mathrm{H}$ NMR.
\end{abstract}

\section{Introduction}

Molecular cages and capsules have been valuable source of knowledge in the understanding of molecular recognition phenomena. ${ }^{[1]}$ The main feature of these structures, is their ability to perform the confinement of guest molecules as molecular host with a well-defined space. Since the early studies by Rebek, ${ }^{[2]}$ it has been reckoned that confinement process is ruled by the complementarity and adaptability, in terms of size and shape among host, guest and solvent. ${ }^{[3]}$ In detail, the interplay of these parameters is determining the thermodynamic and kinetic of the association process. The overall information achieved by these studies has been the basement for the preparation of supramolecular cages with application in sensing, catalysis, transport and delivery. ${ }^{[4]}$

More recently, the use of Dynamic Covalent Chemistry (DCC) ${ }^{[5]}$ to obtain confined systems has largely eased the synthesis of supramolecular architectures with an increasing structural complexity. ${ }^{[6]}$ However, while in principle it is possible to obtain a high number of chemical entities, the fast and reliable

[a] C. Bravin, E. Badetti, F. A. Scaramuzzo, Prof. G. Licini, Prof. C. Zonta

Department of Chemical Sciences

University of Padova

via Marzolo 1, 35131 Padova (PD) (Italy)

E-mail: cristiano.zonta@unipd.it

[b] R. Putreddy, F. Pan, Prof. K. Rissanen

Nanoscience Center, Department of Chemistry

University of Jyvaskyla

P.O. Box 35, Fl-40014, Jyvaskyla (Finland)

Supporting information for this article is given via a link at the end of the document. determination of the energies involved in binding events still remains a time demanding issue. In other words, most of the time the bottleneck is represented by the binding constant determination using ${ }^{1} \mathrm{H}$ NMR analysis. ${ }^{[7]}$ Beside the large amount of information that can be gathered by this technique, ${ }^{[8]}$ competitive experiments where more than one partner is present in solution are difficult to analyse and, as a consequence, every single guest must be investigated individually. In addition, ${ }^{1} \mathrm{H}$ NMR has several limitations in the presence of paramagnetic metals, therefore related ${ }^{1} \mathrm{H}$ NMR spectra are most of the times difficult to interpret. For these reasons, high throughput screening experimental analytical techniques are increasingly used to gather recognition data from DCC experiments. ${ }^{\left[{ }^{[]}\right.}$

In recent years, we have worked with modified tris(pyridylmethyl)amine (TPMA) metal complexes and DCC, ${ }^{[10]}$ to obtain an imine-based zinc self-assembled molecular cage $1 \mathbf{a} \cdot \mathbf{Z n} .^{[11]}$ In detail, we investigated the capability of cage $1 \cdot \mathbf{Z n}$ to include a series of diacids ranging from succinic $\mathbf{C}_{4}$ to tetradecandioic $\mathbf{C}_{14}$ (Scheme 1). This series of diacids were selected to explore how small and somehow linear variations on the structure of the guest can influence the free energy binding profile of the inclusion process. ${ }^{1} \mathrm{H}$ NMR binding constant experiments revealed a pattern displaying a pseudo-Gaussian profile centred on $\mathbf{C}_{\mathbf{8}}$ (Fig. 1).

However, while taking advantage of DCC chemistry for the extension of the cage series with different linker is straightforward ${ }^{[12]}$ the determination of the molecular recognition properties of the novel formed systems via ${ }^{1} \mathrm{H}$ NMR binding experiments requires a titration for every guest. $A$ fast and reliable method would be preferable for a rapid assessment of the binding capabilities of the newly developed systems. ${ }^{[13]}$

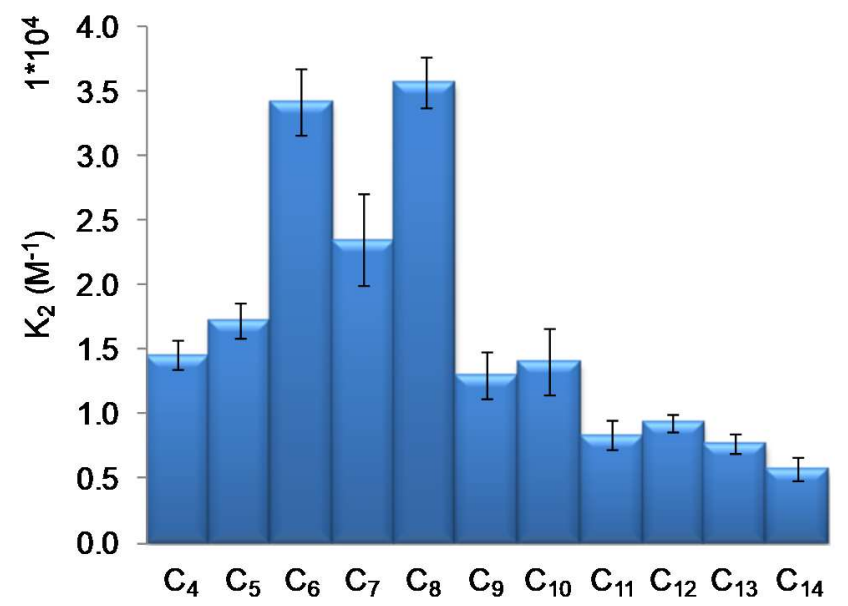

Figure 1. ${ }^{1} \mathrm{H}$ NMR binding constants $\left(\mathrm{K}_{2}\right)$ values for the inclusion of diacids series $C_{4}-C_{14}$ within cage 2 . Solvent is acetonitrile- $d_{3}$. 


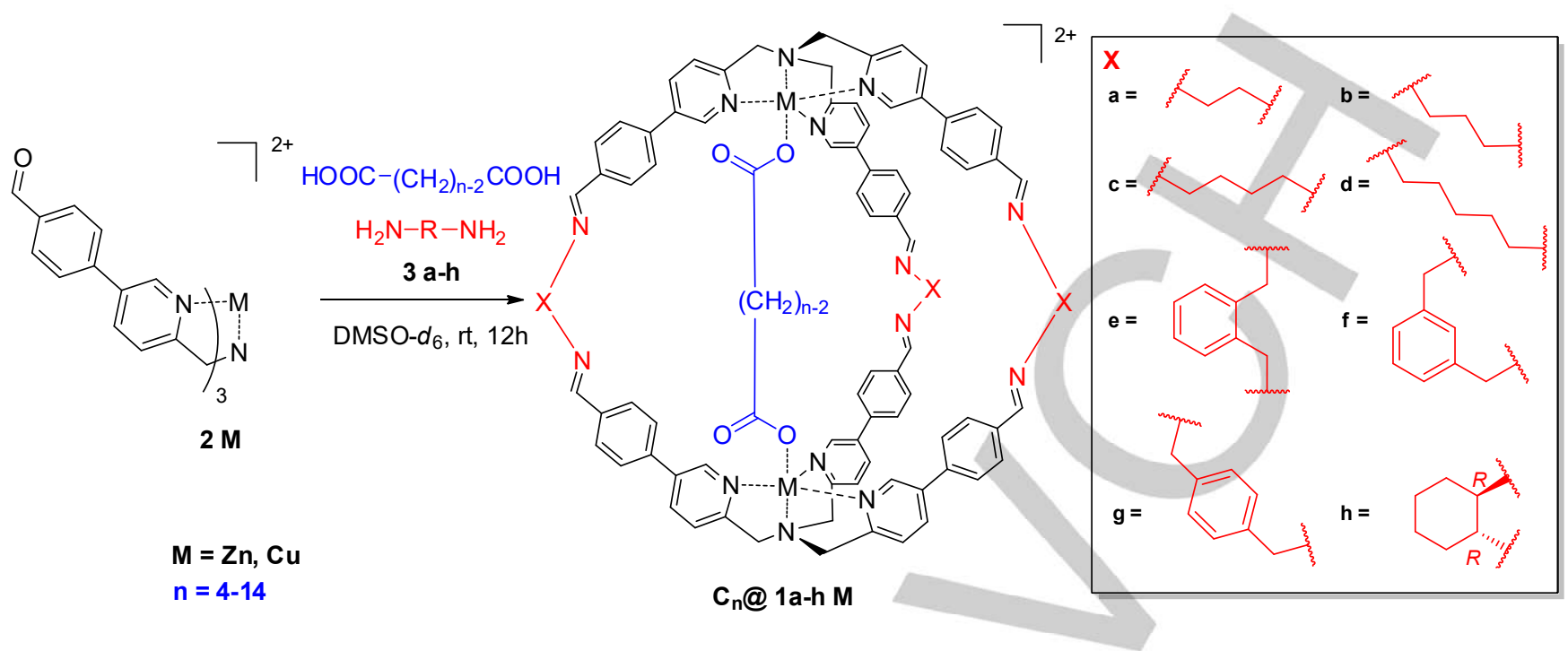

Scheme 1. Synthesis of cages $\mathbf{1 a}-\mathbf{h} \cdot \mathbf{M}$. The reaction of $\mathbf{2} \cdot \mathbf{M}$ (1 equiv) with a diamine $\mathbf{3 a}-\mathbf{h} \mathrm{H}_{2} \mathrm{~N}-\mathrm{R}-\mathrm{NH}_{2}$ (2.5 equiv) in the presence of a suitable diacid $\mathbf{C}_{\mathbf{n}}$ in DMSO$d_{6}$ gives the corresponding bimetallic molecular cages $\mathbf{C}_{\mathbf{n}} @ 1 \mathbf{a}-\mathbf{h} \cdot \mathbf{M}$ in 24 hours. The counteranion is the perchlorate for all the metals.

In this paper, we report the synthesis of fifteen novel molecular cages which differ for the linker and the metal centres of the two TPMA units, together with a study on their recognition properties. The latter was gathered with ESI-MS based competition experiments. The methodological approach developed, allowed not only the rapid evaluation of the binding profile of the newly developed $\mathrm{Zn}$ (II) cages, but also of other eight corresponding $\mathrm{Cu}$ (II) cages, which were completely silent in ${ }^{1} \mathrm{H}$ NMR spectroscopy. Even if the displayed profiles represent relative and not absolute binding energies, deep information on how host and guest small structural variations affect the binding process are retrieved.

\section{Results and Discussion}

\section{Synthesis of novel supramolecular cages with different linkers}

In the initial part of the study, the cages family were extended to diamine linkers different from that used in the previous work, to demonstrate the synthetic versatility of this class of molecular cages and to verify how these linkers were modifying the recognition properties. ${ }^{[14]}$

In detail, we envisaged to extend the cages series started with cage $1 \mathbf{a} \cdot \mathbf{Z n}$, to four aliphatic diamines differing for length of the spacer (1,3-diaminopropane $3 \mathbf{b}$; 1,4-diaminobutane 3c, 1,5diaminopentane $\mathbf{3 d},(1 R, 2 R)$-cyclohexyldiamine $3 \mathbf{h})$ and three xylylenediamines (ortho-xylylenediamine $3 \mathbf{e}$, metaxylylenediamine 3f, para-xylylenediamine $\mathbf{3 g}$ ) (Scheme 1).

As in our previously reported synthesis, the novel cages were formed by the slow addition of the proper diamine linker to a diluted solution of complex $\mathbf{2 \cdot} \mathbf{Z n}$ in the presence of a dicarboxylic acid chosen according to the expected length of the cage. As example, the addition of $3 \mathbf{b}$ diamine linker (2.5 equiv.) to a solution containing suberic acid $\mathbf{C}_{\mathbf{8}}$ ( 0.5 equiv) and complex $\mathbf{2} \cdot \mathbf{Z n}$ (1 equiv) led to the corresponding cage $\mathbf{C}_{8} @ 1 \mathbf{b} \cdot \mathbf{Z n}$ (see Fig. S13). Cage formation was checked with 2D-NMR (COSY,DOSY) (see Fig. S14-15) and MS analysis. Similarly, the extension of the cages series was undertaken for the other diamine linkers. High yields were obtained for all the different linkers confirming the reliability of the synthetic method. Beside the classic characterisation analysis performed for all the cages (see Fig. S10-33), DOSY NMR was also carried out in order to have information on the effect of the diamine linkers length towards the size of the resulting cage. The experimental hydrodynamic radius obtained (see Table S1) showed a good correlation with the radius estimated with semiempirical PM6 calculations for each structure (see Fig. S3). These results confirmed the cage formation in solution and they highlighted the influence of the linker in the modulation of the size of the inner cavity.

\section{ESI-MS Competition Experiment for Cage 1a・Zn}

Once the eight molecular cages were synthesised, we started to investigate how the linkers can influence the binding capability of the novel formed systems toward dicarboxylic acids. In this context, classical ${ }^{1} \mathrm{H}$ NMR titrations would result in more than 80 single titration experiments. For this reason, we explored the possibility to use ESI-MS for a qualitative determination of the molecular recognition properties of the new formed systems. ESIMS represents an ever-growing technique with an increasing capability to interpret molecular recognition events. ${ }^{[15]}$

At first, we set up a competition experiment where all the eleven dicarboxylic acids, ranging from $\mathbf{C}_{\mathbf{4}}$ to $\mathbf{C}_{\mathbf{1 4}}$, were introduced in a solution containing the components for the formation of cage 1a・Zn (Scheme 1). In a typical experiment, the dynamic system is allowed to explore all the possible combinations of binding between the cage and the guests, and to equilibrate thermodynamically toward the more stable inclusion cages. 
(a)

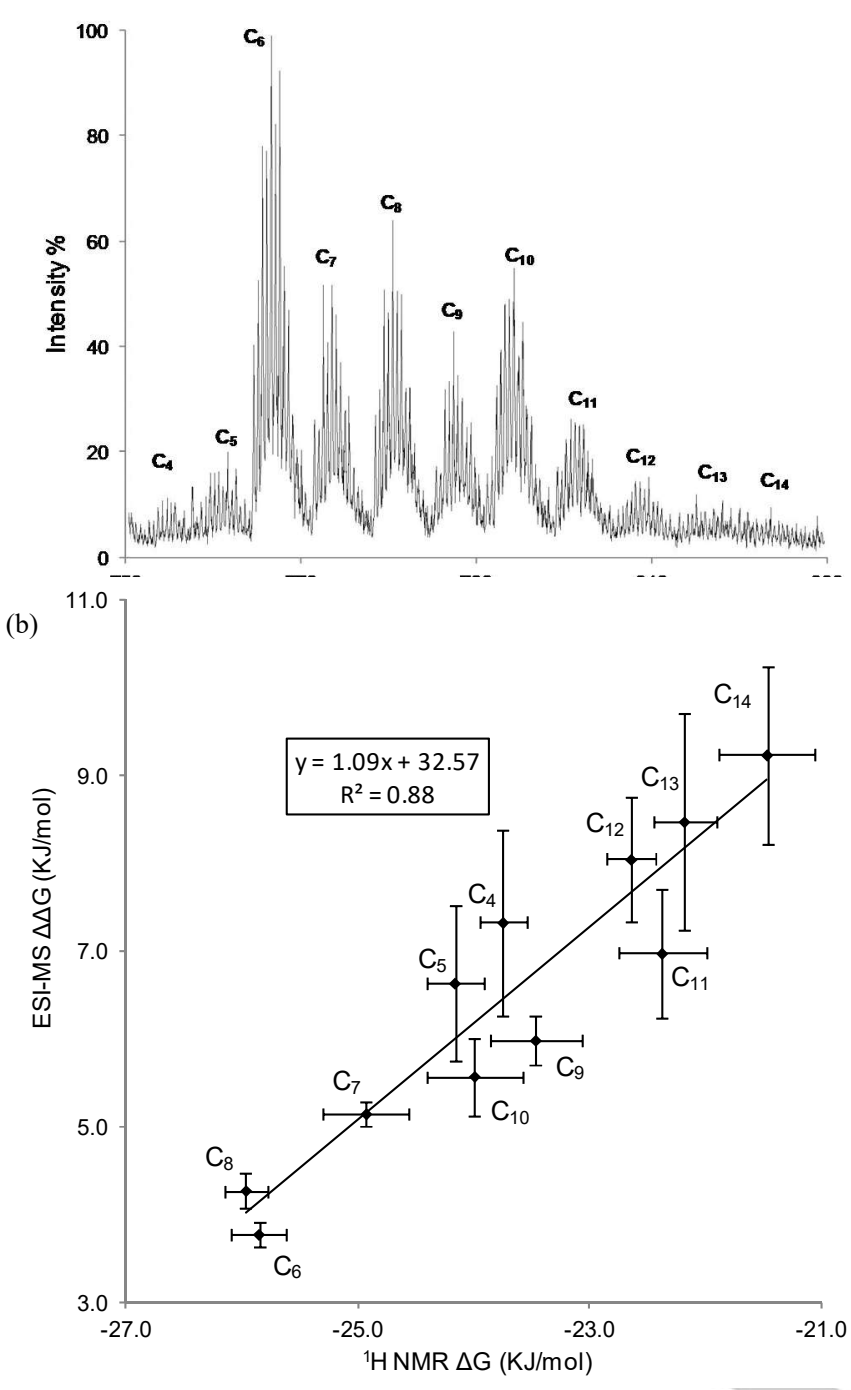

Figure 2. a) ESI-MS profile for the competition experiment of guests, ranging from $\mathrm{C}_{4}$ to $\mathrm{C}_{14}$ ( 1 eq. of each guest), in the presence of cage $1 \mathbf{a} \cdot \mathbf{Z n}$. Each isotopic pattern labelled with $\mathbf{C}_{\mathbf{n}}$ represents the inclusion complex $\mathbf{C}_{\mathbf{n}} @ \mathbf{1 a} \cdot \mathbf{Z n}$. b) Comparison between the $\Delta G$ obtained via ${ }^{1} \mathrm{H}-\mathrm{NMR}$ binding constant determination profile ( $x$ axis) and the $\Delta \Delta G$ values obtained performing the competition experiment with ESI-MS (y axis).

24 hours after mixing the forming components of cage $1 \mathbf{a} \cdot \mathbf{Z n}$ together with the eleven dicarboxylic acids, the reaction mixture, diluted to suitable concentration for MS technique, was injected in the ESI ion source.

The MS spectrometry trace displayed a series of $\mathrm{m} / \mathrm{z}$ peaks corresponding to the eleven different inclusion cages (Fig. 2a)

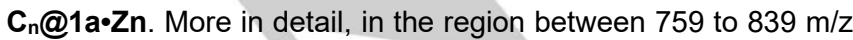
were present the double charged clusters related to the inclusion complexes $\mathbf{C}_{\mathbf{n}} @ \mathbf{1} \mathbf{a} \cdot \mathbf{Z n}$ with their characteristic isotopic pattern.

As it can be seen at first glance, the MS trace of the competition experiment strongly reminds the binding constant profile measured using single ${ }^{1} \mathrm{H}$ NMR experiments. In this case, the highest peak is corresponding to the $\mathbf{C}_{6} @ 1 \mathbf{a} \cdot \mathbf{Z n}$ inclusion complex and it is still possible to observe the characteristic oddeven distribution pattern present also in the ${ }^{1} \mathrm{H}$ NMR titration experiment. This is noteworthy, taking into account that the energetic difference from neighbour guests in the series is small (e.g. the energy difference calculates from ${ }^{1} \mathrm{H}$ NMR between C9@1a・Zn and $\mathbf{C}_{10} @ 1 \mathrm{a} \cdot \mathrm{Zn}$ is $0.5 \mathrm{~kJ} / \mathrm{mol}$ ).

In order to have a more detailed comparison among the two analyses, the relative intensity of the monoisotopic peaks in the ESI-MS was correlated with the NMR experiments (Fig. 2b). In particular, the binding constant values obtained via ${ }^{1} \mathrm{H}$ NMR and the intensity peaks of ESI-MS were converted into the corresponding $\Delta G$ and $\Delta \Delta G$ respectively (see Table S2). A good linear correlation confirms the initial visual impression of the ESIMS trace. The experimental points tend to stay close to the line of tendency and the slope of the linear correlation is close to unity. As the inclusion complexes $\mathbf{C}_{\mathbf{n}} @ 1 \mathbf{a} \cdot \mathbf{Z n}$ are structurally similar, and the correlation expressed between $\Delta G$ and $\Delta \Delta G$ obtained respectively from ${ }^{1} \mathrm{H}$ NMR and ESI-MS is linear, we assume that

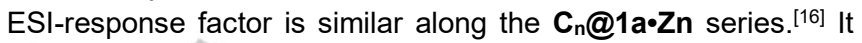
should be noted that in principle in solution and gas-phase analysis can differ very much. In addition, it is worth of notice that the signals related to inclusion complexes with smaller binding constants $\left(\mathbf{C}_{4}, \mathbf{C}_{5}, \mathbf{C}_{11}, \mathbf{C}_{12}, \mathbf{C}_{14}\right)$ are slightly over estimated and they tend to have high values of standard deviation. This error can arise from a more important contribution of the baseline noise. Nevertheless, the developed methodology can offer in a couple of minutes of acquisition a qualitative determination of the selected inclusion cage, which open to the possibility to have a good estimation on cage selectivity toward guest of increasing size.

\section{ESI-MS Competition Experiment for Cages $1 a-h \cdot Z n$}

After establishing the reliability of the ESI-MS competition method, we applied this approach to other cages with the same diacids series. The analysis was carried out in a similar fashion to the $\mathbf{1 a} \cdot \mathbf{Z n}$ cage. Molecular cages $\mathbf{1 b}-\mathbf{h} \cdot \mathbf{Z n}$ were prepared in DMSO solution performing a competition experiment in which were present all diacids, from succinic $\mathbf{C}_{4}$ to tetradecandioic $\mathbf{C}_{14}$. The solution was checked after 24 hours by ${ }^{1} \mathrm{H}$ NMR, to evaluate the complete disappearance of the aldehyde signal, and by ESI-MS analysis. The results expressed for each competition experiment as selectivity profiles are reported in Figure 3 (see Fig. S1).

From the novel set of experiments, it is possible to notice that the new cages can incorporate all the diacids of the series. Interestingly, there is an evident modulation on the selectivity profile dictated by the characteristics of the diamine linker. As example, in the case of propyl linker $\mathbf{1 b}$ it is possible to observe a widespread pseudo-Gaussian profile centred between suberic acid $\mathbf{C}_{8}$ and sebacic acid $\mathbf{C}_{10}$. In general, $\mathbf{C}_{\mathbf{1 0}}$ shows the strongest interaction within the cage while shorter diacids $\mathbf{C}_{4-9}$, as well as longer diacids $\mathbf{C}_{11-14}$, display a lower intensity. This behaviour is due to the thermodynamic cost for a conformational rearrangement of the host and the guest to perform the recognition process. 


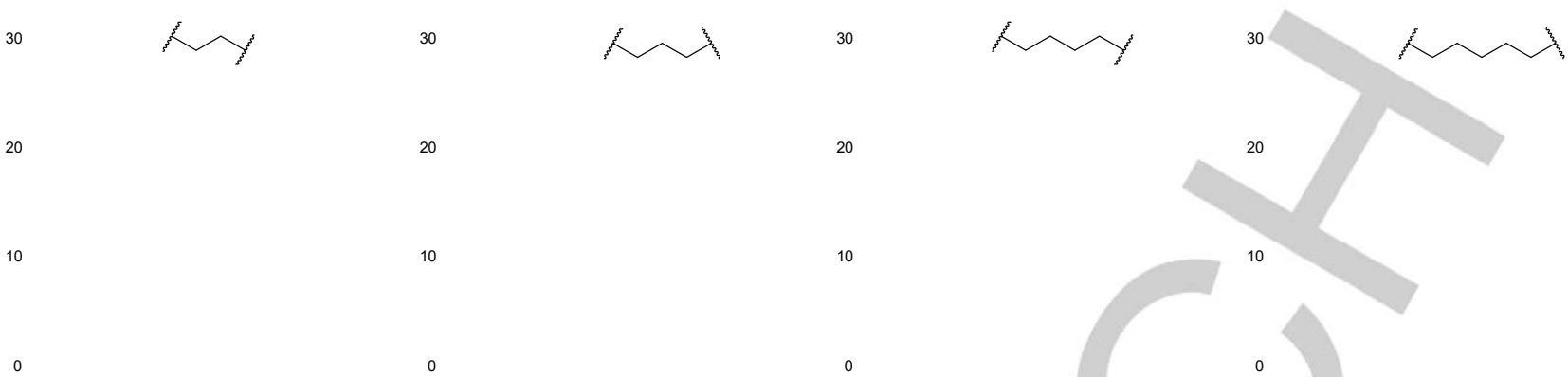

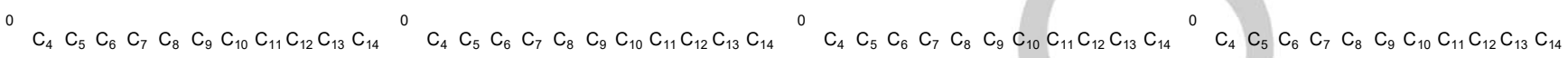
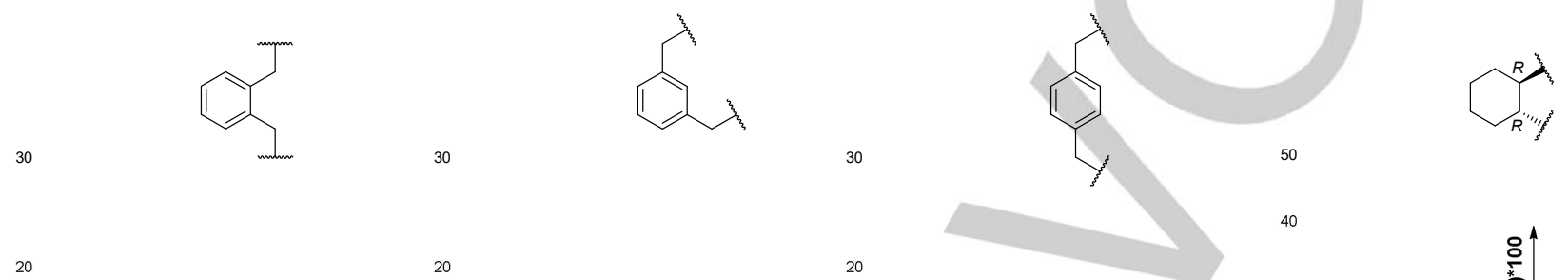

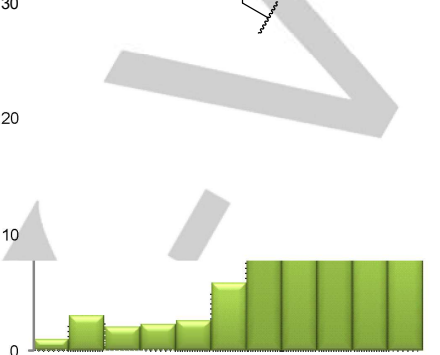

$\begin{array}{lllllllllll}\mathrm{C}_{4} & \mathrm{C}_{5} & \mathrm{C}_{6} & \mathrm{C}_{7} & \mathrm{C}_{8} & \mathrm{C}_{9} & \mathrm{C}_{10} & \mathrm{C}_{11} & \mathrm{C}_{12} \mathrm{C}_{13} & \mathrm{C}_{14}\end{array}$

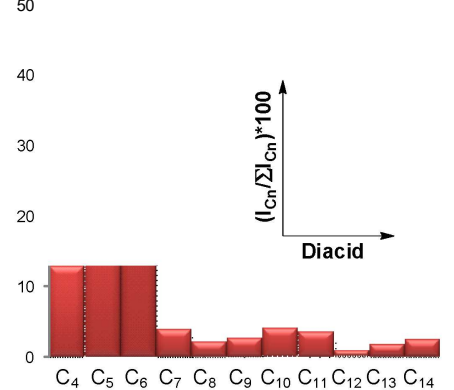

Figure 3. ESI-MS selectivity profiles for $\mathbf{C}_{\mathbf{n}} @ \cdot 1 \mathrm{a}-\mathbf{h} \mathbf{Z n}$ in the competition experiments. The general observation for all the profile series relies that to an elongation of the diamine linker corresponds a shift to longer diacids as more suitable guests. In the same fashion increasing the flexibility of the linker a wider distribution of the preferential guests is observed. The analysis of the binding profile leads to the following values of weighted arithmetic mean $\left(x_{c}\right)$ : $\mathbf{a}=8.05 ; \mathbf{b}=9.23 ; \mathbf{c}=9.57 ; \mathbf{d}=9.67$; $\mathbf{e}=9.77 ; \mathbf{f}=10.76 ; \mathbf{g}=10.95 ; \mathbf{h}=6.39$. The error for each experiment are reported in the Supporting Information (Table S3)

In other words, to an elongation of diamine linker, from ethylendiamine $\mathbf{1 a}$ to 1,3 -propylendiamine $\mathbf{1 b}$, the main effect is the shift of the maximum in ESI-MS spectra from $\mathbf{C}_{6}$ to $\mathbf{C}_{10}$. This observation could be translated in a quantitative data considering the weighted arithmetic mean of each distribution $\left(\mathrm{x}_{\mathrm{c}}\right)$.

In the case of ethylendiamine $1 a$ the $x_{c}$ value is 8.05 and it shifts to 9.23 for the propyl linker $\mathbf{1 b}$. In the case of longer diamine linkers, namely 1,4-butyldiamine $\mathbf{1 c}$ and 1,5-pentyldiamine $\mathbf{1 d}$, it is possible to observe a small and continuous shift toward longer dicarboxylic guests. While the preferential guest is still the diacid $\mathbf{C}_{10}$ for both cages formed by the longer linkers $\left(x_{c}=9.57\right.$ for $1 \mathrm{c}$ and 9.67 for 1d), longer diacids tends to be recognized to a higher extent. Similar considerations explain the ESI-MS traces for the three xylylendiamine linkers (ortho-xylylenediamine 1e, metaxylylenediamine 1f, para-xylylenediamine 1g). In these systems, to an enlargement of the size cavity due to the presence of xylyl linkers, corresponds a small shift towards longer diacids, though the preferential guest still remains the diacid $\mathbf{C}_{10}\left(x_{c}=9.77\right.$ for $1 e$, 10.76 for $\mathbf{1 f}$ and $\mathbf{1 0 . 9 5}$ for $\mathbf{1 g}$ ).

A remarkable change in the shape of the competition curve is observed for the cage formed by $1 R, 2 R$-cyclohexyl linker $\mathbf{1 h} \cdot \mathbf{Z n}$.
A narrow selectivity profile centred on adipic acid $\mathbf{C}_{6}\left(\mathrm{x}_{\mathrm{c}}=6.39\right)$ is observed for the competition experiment of $\mathbf{1 h \cdot Z n ~ c a g e . ~ T h i s ~}$ peculiar selectivity toward shorter diacids with respect to the previous case can be explained by the decreased geometrical distance between the two imine nitrogen atoms present in the cage. On the other hand, the higher selectivity of $\mathbf{1 h} \cdot \mathbf{Z n}$ towards two diacids is a direct consequence of the restriction in the available conformations imposed by the cyclohexyl ring of the c linker. While it has been previously observed that tight linkers support cage formation, ${ }^{[17]}$ this is the first example of inclusion complex in which to a tightening of the supramolecular architecture corresponds a higher selectivity.

In summary, $\mathbf{1} \mathbf{a}-\mathbf{b} \cdot \mathbf{Z n}$ cages are characterized by a recognition profile centred between $\mathbf{C}_{\mathbf{6}}$ and $\mathbf{C}_{\mathbf{1 0}}$. To an increase of the length of the aliphatic diamine linker (from ethyl 1a to pentyl 1d), longer diacids get preferentially recognised and the distribution of guests' selectivity becomes slightly wider. In the same fashion, the selectivity of the xylylen series of cages $1 \mathrm{e}-1 \mathrm{f}-1 \mathrm{~g}$ is modulated by

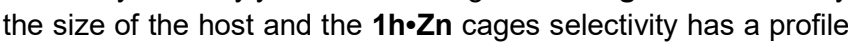
ruled by the geometry and stiffness of the linker. 


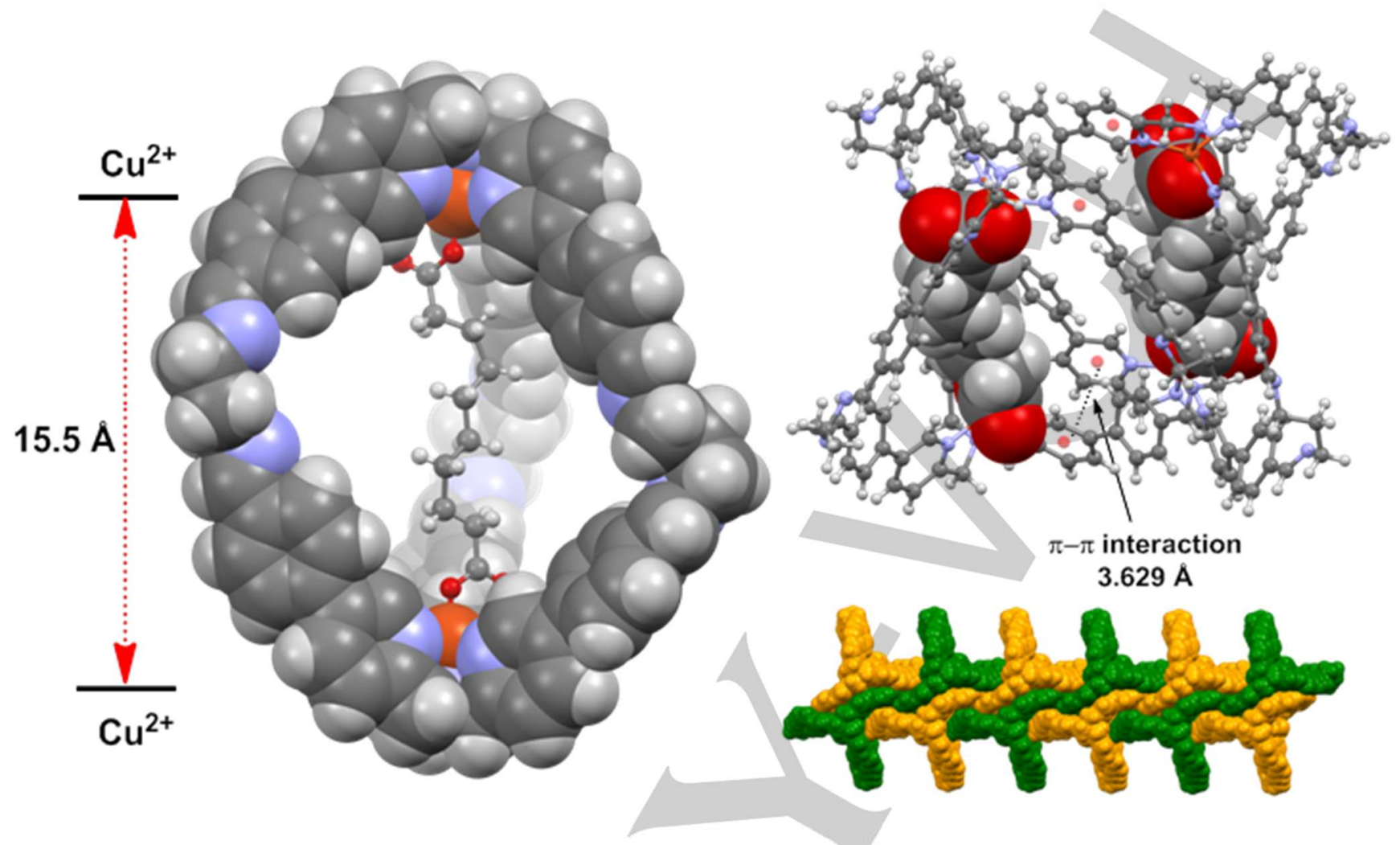

Figure 4. (a) X-ray crystal structure of $\mathbf{C}_{10} @ 1 \mathbf{b} \cdot \mathbf{C u}$ in CPK model displaying the entrapment of sebacic acid $\mathbf{C}_{10}$ (ball \& stick model) inside the cage. (b) Section of 3-D packing to highlight $\pi-\pi$ stabilization of $\mathbf{C}_{10} @ 1 \mathbf{b} \cdot \mathbf{C}$ u cage entities. The sebacic acid $\mathbf{C}_{10}$ is shown in CPK model. (c) 1-D polymer formation.

\section{Copper cages and X-Ray crystal structure of $C_{10} @ 1 b \cdot C u$}

A strong limitation of binding constant determination via ${ }^{1} \mathrm{H}$ NMR is represented, in the chemistry of self-assembled architectures, by structures containing paramagnetic metals. In fact, paramagnetic metal centres are known to make complicate spectral assignment due to line broadening and large changes in chemical shifts. ${ }^{[18]}$

In this context, we were interested in the use of a paramagnetic metal, such as $\mathrm{Cu}(\mathrm{II})$ coordinated to TPMA unit, ${ }^{[19]}$ but these systems are typical examples of structures that are difficult to monitor by ${ }^{1} \mathrm{H}$ NMR. It was also impossible to achieve values of the binding constants by UV titrations because the cage chromophores were only slightly influenced by the binding event and significative variations in the absorption bands, before and after the guest addition, were not detected.

To evaluate if the ESI-MS methodology was able to support also paramagnetic metals, we synthetised $\mathrm{Cu}(\mathrm{II})$ cages starting from the TPMA copper complex $\mathbf{2} \cdot \mathbf{C u}$ (Scheme 1), following the same conditions previously described. As for zinc cages, for each of the eight diamine linkers the corresponding copper cages were obtained, and the recognition properties toward a single dicarboxylic acid were investigated. Among these structures, good quality single crystals suitable for X-ray were obtained for the $\mathbf{C}_{10} @ 1 \mathbf{b} \cdot \mathbf{C u}$ inclusion complex (Fig. 4). Cage $\mathbf{C}_{10} @ 1 \mathbf{b} \cdot \mathbf{C u}$ is very compact and acquires $15.5 \AA$ between the two metal centres (Fig. 4a) to accommodate sebacic acid $\mathbf{C}_{10}$.

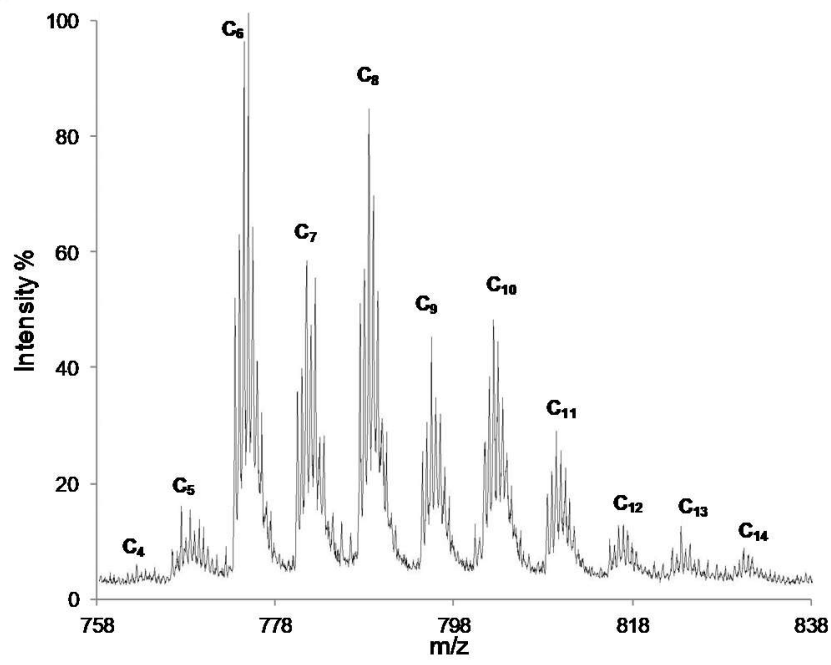

Figure 5. ESI-MS profile for the competition experiment of guests ranging from $\mathbf{C}_{4}$ - to $\mathbf{C}_{14}$ (1 eq. of each guest) in the presence of 1 equivalent of cage $1 \mathbf{a} \cdot \mathbf{C u}$. Each isotopic pattern labelled with $\mathbf{C}_{\mathbf{n}}$ represents the inclusion complex $\mathrm{C}_{\mathrm{n}} @ 1 \mathrm{a} \cdot \mathrm{Cu}$ 


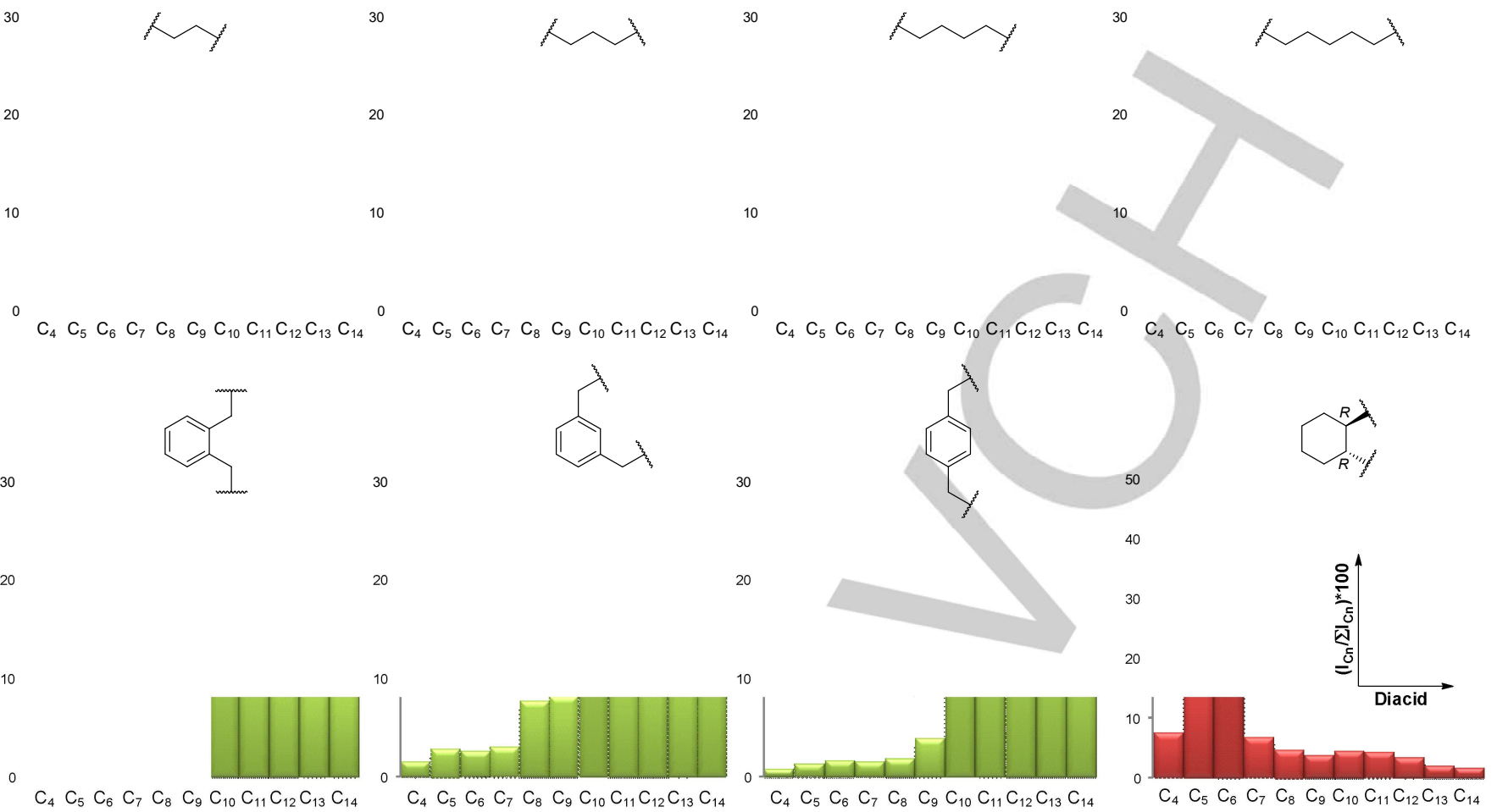

Figure 6. ESI-MS selectivity profiles for $\mathbf{C}_{n} @ 1 \mathbf{a}-\mathbf{h} \cdot \mathbf{C u}$ in the competition experiments. The general observation for all the profile series is similar to that obtained for 2.Zn complex. A moderate shift of the maximum is observed in the $\mathbf{C}_{\mathbf{n}} @ \mathbf{1 a}-\mathbf{h} \cdot \mathbf{C} \mathbf{u}$ cages as expected by the already know shortening of the distance of the metal from the tertiary amine of the ligand. In virtue of this structural variation, longer diacids can accommodate within these cages with respect to the corresponding zinc cages. The analysis of the binding profile lead to the following values of weighted arithmetic mean $\left(x_{c}\right)$ respect to the diacid series: $\mathbf{a}=8.27 ; \mathbf{b}=8.85 ; \mathbf{c}=8.93 ; \mathbf{d}=10.40$; $\mathbf{e}=10.00 ; \mathbf{f}=10.64 ; \mathbf{g}=11.32 ; \mathbf{h}=6.84$. The error for each experiment are reported in the Supporting Information (Table S3).

Because of the flexible cage side arms, and close packing, $\mathbf{C}_{10} @ 1 \mathbf{1 b} \cdot \mathrm{Cu}$ units remarkably displays $\pi-\pi$ interactions at centroid-to-centroid distances of $3.629 \AA$ (Fig. 4b), subtly responsible for disordered encapsulated $\mathbf{C}_{10}$. The $\pi-\pi$ interactions are extended one dimensionally (Fig. 4c), and the resultant 1-D polymers inter-digitates to promote an efficient and complex 3-D network.

After establishing the recognition properties of copper(II) cages, competition experiments of the diacid $\mathbf{C}_{4}-\mathbf{C}_{14}$ toward the $\mathbf{1 a - h} \cdot \mathbf{C u}$ family were performed as for $\mathbf{1} \mathbf{a}-\mathbf{h} \cdot \mathbf{Z n}$ cage series. ESI-MS trace (see Fig. S2) is analogous, beside the difference related to the isotopic pattern of copper, to the profiles reported for the zinc cages (Fig. 3). Also in these cases, it is possible to observe selectivity profiles which are similar in shape and intensity to the corresponding 1a-h•Zn family (Fig. 6) and similar considerations on the effect of the linkers can be taken. Interestingly, a closer look to the selectivity profiles reveals a small difference with respect to zinc cages. The selectivity profiles in fact, are always slightly shifted towards longer guests. This variation was expected, and it arises from the shorter distance between the copper and the tertiary amine of the ligand, allowing to accommodate longer guests than the zinc(II) series. ${ }^{[20]}$ The strong correlation between zinc(II) and copper(II) profiles, together with the possibility to accommodate longer diacids for the copper(II) series, corroborate the use of ESI-MS profiles for the analysis of copper(II) cages, which was not possible otherwise.

\section{Conclusions}

In conclusion, seven zinc(II) and eight copper(II) novel molecular cages differing in size have been synthesized. The selectivity profiles have been investigated using an ESI-MS methodological approach that allows to perform a competition experiment in which all the eleven diacid guests are present in the reaction mixture. This approach has shown to furnish selectivity profiles that are well correlated with NMR titration in the case of $\mathbf{1 a \cdot Z n}$ cage. More importantly, the technique proposed can be used also for copper(II) systems which cannot be investigate either via ${ }^{1} \mathrm{H}$ NMR or UV-Vis titrations.

In summary, all molecular cages synthetized in this work are able to bind dicarboxylic acids, and competition experiments have shown trends in molecular recognition properties dictated by the complementarity and adaptability of the binding partners. These results give interesting knowledge on how different linkers can modulate the flexibility and size of the resulting molecular cages, and their influence in the recognition events. Besides increasing the knowledge on molecular recognition events, the possibility to 
have high throughput information on the binding capabilities of these systems pave the way for the development of more selective and functional cages.

\section{Experimental Section}

\section{General procedure for the synthesis of complexes}

$0.10 \mathrm{mmol}$ of ligand 4,4',4"-(6,6',6"-(nitrilotris(methylene))tris(pyridine6,3diyl))tribenzaldehyde 1 were dissolved in acetonitrile $(15 \mathrm{ml})$ and 0.10 $\mathrm{mmol}$ of the corresponding metal perchlorates hexahydrate were added. The solution was stirred at room temperature for 1 hour and the reaction was followed by ${ }^{1} \mathrm{H}$ NMR and ESI-MS. At the end of the reaction diethyl ether $(25 \mathrm{ml})$ was added obtaining quantitatively a crystalline solid then centrifuged and dried. $\mathbf{2} \cdot \mathbf{Z n}$ (pale yellow solid, yield $95 \%)$. ${ }^{1} \mathrm{H}$ NMR $(300$ $\mathrm{MHz}, \mathrm{CD} 3 \mathrm{CN}$ ) $\delta$ (ppm): 10.09 (s, 3H, CHO), 8.82 (d, 3H, J=2.0 Hz, PyrH), 8.44 (dd, $3 \mathrm{H}, \mathrm{J}=8.0 \mathrm{~Hz}, \mathrm{~J}=2.0 \mathrm{~Hz}$ PyrH), 8.07 (d, $6 \mathrm{H}, \mathrm{J}=8.0 \mathrm{~Hz}$, ArH), 7.94 (d, $6 \mathrm{H}, \mathrm{J}=8.0 \mathrm{~Hz}, \mathrm{ArH}), 7.75$ (d, 3H, J=8.0 Hz, PyrH), 4.40 (s, 6H,CH2). HRMS (ESI-TOF) (m/z): [M+ClO4]+ calcd. for [C39H3ON4O3Zn+ClO4]+, 765.1094; found 765.1165. Elemental analysis: C. 54.08; H, 4.01; N, 6.85. Required $[1 \cdot \mathrm{Zn}](\mathrm{ClO} 4) 2 . \mathrm{C} 54.03 ; \mathrm{H}, 3.49 ; \mathrm{N}, 6.46 .2 \cdot \mathrm{Cu}$ (dark green solid, yield $98 \%$ ). ${ }^{1} \mathrm{H}$ NMR (300 MHz, CD3CN) $\delta(p p m): 10.11$ (s), 8.57 (d), 8.29 (s). HRMS (ESI-TOF) (m/z): [M+ClO4]+ calcd. for [C39H30N4O3Cu+ClO4]+ 760.1135; found, 760.1202. Elemental analysis: C. 54.23; $\mathrm{H}, 4.02 ; \mathrm{N}, 5.88$. Required: $[1 \cdot \mathrm{Cu}](\mathrm{ClO} 4) 2 \mathrm{C} 54.14 ; \mathrm{H}$, $3.50 ; \mathrm{N}, 6.48$.

General procedure for the synthesis of molecular cages $\mathbf{C n}_{n} @ 1 \mathrm{1a}-\boldsymbol{h} \cdot \mathbf{Z n}$

To $500 \mu \mathrm{l}(1.0 \mu \mathrm{mol})$ of a solution $0.002 \mathrm{M}$ of complex $2 \cdot \mathbf{Z n}$ in DMSO- $\mathrm{d}_{6}$ $50 \mu \mathrm{l}(0.5 \mu \mathrm{mol})$ of a solution $0.01 \mathrm{M}$ in DMSO- $\mathrm{d}_{6}$ of dicarboxylic acid $\mathrm{C}_{\mathrm{n}}$ and $125 \mu \mathrm{l}(2.5 \mu \mathrm{mol})$ of a solution $0.02 \mathrm{M}$ in DMSO-d of a diamine $4 \mathrm{a}-\mathrm{h}$ were added in a NMR tube. The mixture was left for 12 hour at room temperature and checked via ${ }^{1} \mathrm{H}$ NMR and ESI-MS. The yield for all the cages are $>90 \%$ (Determined via ${ }^{1} \mathrm{H}$ NMR on internal standard $p$-xilene). $\mathrm{C}_{6} @ 1 \mathrm{a} \cdot \mathrm{Zn}{ }^{1} \mathrm{H}$ NMR $\left(400 \mathrm{MHz}, \mathrm{DMSO}-d_{6}\right) \delta$ (ppm): 9.06 (s, 6H, PyrH), 8.46 (dd, $6 \mathrm{H}, J=8.0 \mathrm{~Hz}, J=2.0 \mathrm{~Hz}, \mathrm{PyrH}), 8.40\left(\mathrm{~s}, 6 \mathrm{H}, \mathrm{NH}_{\mathrm{imm}}\right), 7.93(\mathrm{~d}, 12 \mathrm{H}$, $\mathrm{J}=8.0 \mathrm{~Hz}, \mathrm{ArH}), 7.80(\mathrm{~m}, 12 \mathrm{H}+6 \mathrm{H}, \mathrm{PyrH}+\mathrm{ArH}), 4.36\left(\mathrm{~s}, 12 \mathrm{H}, \mathrm{CH}_{2}\right), 3.94(\mathrm{~m}$,

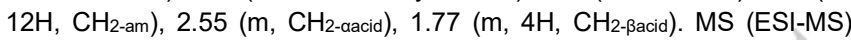
$(\mathrm{m} / \mathrm{z})$ : $[\mathrm{M}]^{2+}$ calcd. for $\left[\mathrm{C}_{90} \mathrm{H}_{80} \mathrm{~N}_{14} \mathrm{O}_{4} \mathrm{Zn}_{2}\right]^{2+}, 775.3$ found; $775.4 \mathrm{C}_{8} @ 1 \mathrm{~b} \cdot \mathrm{Zn}$ ${ }^{1} \mathrm{H}$ NMR $\left(400 \mathrm{MHz}, \mathrm{DMSO}-\mathrm{d}_{6}\right) \delta(\mathrm{ppm}): 9.09(\mathrm{~s}, 6 \mathrm{H}, \mathrm{PyrH}), 8.55$ (dd, $6 \mathrm{H}$, $J=8.0 \mathrm{~Hz}, J=2.0 \mathrm{~Hz}, \mathrm{PyrH}), 8.47$ (s, $\left.6 \mathrm{H}, \mathrm{NH}_{\mathrm{imm}}\right), 7.98$ (d, $12 \mathrm{H}, J=8.0 \mathrm{~Hz}$, $\mathrm{ArH}), 7.81(\mathrm{~m}, 12 \mathrm{H}+6 \mathrm{H}, \mathrm{PyrH}+\mathrm{ArH}), 4.44\left(\mathrm{~s}, 12 \mathrm{H}, \mathrm{CH}_{2}\right), 3.69\left(\mathrm{~m}, 12 \mathrm{H}, \mathrm{CH}_{2}\right.$

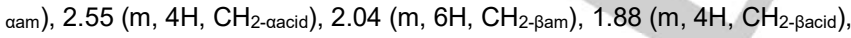

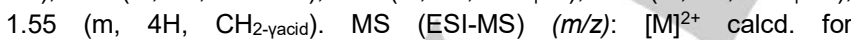
$\left[\mathrm{C}_{95} \mathrm{H}_{90} \mathrm{~N}_{14} \mathrm{O}_{4} \mathrm{Zn}_{2}\right]^{2+}, 810.8$ found; $810.7 \mathrm{C}_{10} @ 1 \mathrm{c} \cdot \mathrm{Zn}{ }^{1} \mathrm{H}$ NMR $(400 \mathrm{MHz}$, DMSO-d 6 ) $\delta$ (ppm): 9.14 (s, 6H, PyrH), 8.56 (dd, $6 \mathrm{H}, J=8.0 \mathrm{~Hz}, J=2.0 \mathrm{~Hz}$, PyrH), 8.47 (s, 6H, NH imm), 7.90 (d, 12H, J=8.0 Hz, ArH), $7.83(\mathrm{~m}, 12 \mathrm{H}+6 \mathrm{H}$, PyrH+ArH), $4.41\left(\mathrm{~s}, 12 \mathrm{H}, \mathrm{CH}_{2}\right), 3.67\left(\mathrm{~m}, 12 \mathrm{H}, \mathrm{CH}_{2 \text {-am }}\right), 1.89\left(\mathrm{~m}, 4 \mathrm{H}, \mathrm{CH}_{2}\right.$

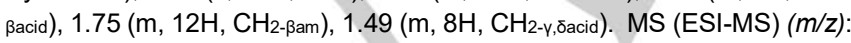
$[\mathrm{M}]^{2+}$ calcd. for $\left[\mathrm{C}_{100} \mathrm{H}_{100} \mathrm{~N}_{14} \mathrm{O}_{4} \mathrm{Zn}_{2}\right]^{2+}$, 845.9 found; $845.7 \mathrm{C}_{10} @ 1 \mathrm{~d} \cdot \mathbf{Z n}{ }^{1} \mathrm{H}$ NMR (400 MHz, DMSO- $\left.d_{6}\right) \delta$ (ppm): 9.11 (s, 6H, PyrH), 8.52 (dd, 6H, $J=8.0 \mathrm{~Hz}, \mathrm{~J}=2.0 \mathrm{~Hz}, \mathrm{PyrH}$ ), 8.45 (s, $6 \mathrm{H}, \mathrm{NH}$ imm), 7.94 (d, $12 \mathrm{H}, \mathrm{J}=8.0 \mathrm{~Hz}$, ArH), $7.80(\mathrm{~m}, 12 \mathrm{H}+6 \mathrm{H}, \mathrm{PyrH}+\mathrm{ArH}), 4.43\left(\mathrm{~s}, 12 \mathrm{H}, \mathrm{CH}_{2}\right), 3.62\left(\mathrm{~m}, 12 \mathrm{H}, \mathrm{CH}_{2}\right.$

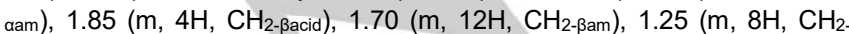
v. oacid). MS (ESI-MS) (m/z): [M] $]^{2+}$ calcd. for $\left[\mathrm{C}_{103} \mathrm{H}_{106} \mathrm{~N}_{14} \mathrm{O}_{4} \mathrm{Zn}_{2}\right]^{2+}, 866.9$ found; 866.9. $\mathbf{C}_{8} @ 1 \mathrm{e} \cdot \mathrm{Zn}^{1}{ }^{1} \mathrm{H}$ NMR (400 MHz, DMSO- $\left.d_{6}\right) \delta(\mathrm{ppm}): 9.11$ (s, $6 \mathrm{H}, \mathrm{PyrH}), 8.62$ (s, 6H, NH imm), 8.54 (dd, $6 \mathrm{H}, J=8.0 \mathrm{~Hz}, J=2.0 \mathrm{~Hz}, \mathrm{PyrH})$, $7.99(\mathrm{~d}, 12 \mathrm{H}, \mathrm{J}=8.0 \mathrm{~Hz}, \mathrm{ArH}), 7.82(\mathrm{~m}, 12 \mathrm{H}+6 \mathrm{H}, \mathrm{PyrH}+\mathrm{ArH}), 7.30(\mathrm{~m}, 12 \mathrm{H}$,

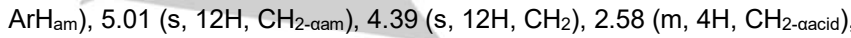
$1.84\left(\mathrm{~m}, 4 \mathrm{H}, \mathrm{CH}_{2 \text {-racid }),} 1.51\right.$ (m, 4H, $\mathrm{CH}_{2 \text {-vacid). }}$ MS (ESI-MS) $(\mathrm{m} / \mathrm{z}):[\mathrm{M}]^{2+}$ calcd. for $\left[\mathrm{C}_{110} \mathrm{H}_{96} \mathrm{~N}_{14} \mathrm{O}_{4} \mathrm{Zn}_{2}\right]^{2+}, 903.8$ found; 903.9. $\mathbf{C}_{10} @ 1 \mathrm{f} \bullet \mathrm{Zn}{ }^{1} \mathrm{H}$ NMR $\left(400 \mathrm{MHz}, \mathrm{DMSO}-d_{6}\right) \delta(\mathrm{ppm}): 9.11(\mathrm{~s}, 6 \mathrm{H}, \mathrm{PyrH}), 8.61\left(\mathrm{~s}, 6 \mathrm{H}, \mathrm{NH}_{\mathrm{imm}}\right)$, $8.53(\mathrm{dd}, 6 \mathrm{H}, \mathrm{J}=8.0 \mathrm{~Hz}, \mathrm{~J}=2.0 \mathrm{~Hz}, \mathrm{PyrH}), 7.96(\mathrm{~d}, 12 \mathrm{H}, \mathrm{J}=8.0 \mathrm{~Hz}, \mathrm{ArH})$, $7.83(\mathrm{~m}, 12 \mathrm{H}+6 \mathrm{H}, \mathrm{PyrH}+\mathrm{ArH}), 7.34\left(\mathrm{~m}, 6 \mathrm{H}, \mathrm{ArH}_{\mathrm{am}}\right), 7.23\left(\mathrm{~m}, 6 \mathrm{H}, \mathrm{ArH}_{\mathrm{am}}\right)$

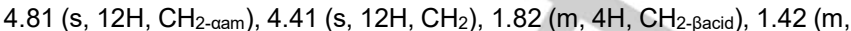
$4 \mathrm{H}+4 \mathrm{H}, \quad \mathrm{CH}_{2-\gamma, \bar{\delta}}$ acid). MS (ESI-MS) $(\mathrm{m} / \mathrm{z}): \quad[\mathrm{M}]^{2+}$ calcd. for $\left[\mathrm{C}_{112} \mathrm{H}_{100} \mathrm{~N}_{14} \mathrm{O}_{4} \mathrm{Zn}_{2}\right]^{2+}, 904.4$ found; 904.4. $\mathrm{C}_{10} @ 1 \mathrm{~g} \cdot \mathrm{Zn}{ }^{1} \mathrm{H} \mathrm{NMR}(400 \mathrm{MHz}$, DMSO-d d $\delta$ (ppm): $9.09(\mathrm{~s}, 6 \mathrm{H}, \mathrm{PyrH}), 8.56(\mathrm{~s}, 6 \mathrm{H}, \mathrm{NH}$ imm), 8.51 (dd, $6 \mathrm{H}$ $J=8.0 \mathrm{~Hz}, \mathrm{~J}=2.0 \mathrm{~Hz}, \mathrm{PyrH}), 7.95(\mathrm{~d}, 12 \mathrm{H}, \mathrm{J}=8.0 \mathrm{~Hz}, \mathrm{ArH}), 7.80(\mathrm{~m}, 12 \mathrm{H}+6 \mathrm{H}$, PyrH+ArH), 7.32 (s, 6H, ArHam), $7.32\left(\mathrm{~s}, 12 \mathrm{H}, \mathrm{ArH}_{\mathrm{am}}\right) 4.81\left(\mathrm{~s}, 12 \mathrm{H}, \mathrm{CH}_{2}\right.$ aam), 4.38 (s, 12H, $\left.\mathrm{CH}_{2}\right), 1.74$ (m, 4H, $\left.\mathrm{CH}_{2-\beta a c i d}\right), 1.34$ (m, 4H+4H, $\mathrm{CH}_{2-\gamma, \overline{0}}$ acid). MS (ESI-MS) (m/z): [M] ${ }^{2+}$ calcd. for $\left[\mathrm{C}_{112} \mathrm{H}_{100} \mathrm{~N}_{14} \mathrm{O}_{4} \mathrm{Zn}_{2}\right]^{2+}, 904.4$ found; 904.5. C 61 1h·Zn ${ }^{1} \mathrm{H}$ NMR (400 MHz, DMSO- $\left.d_{6}\right) \delta$ (ppm): 8.88 (s, $6 \mathrm{H}, \mathrm{PyrH}$ ), 8.41 (s, $6 \mathrm{H}, \mathrm{NH}$ imm), 8.35 (dd, $6 \mathrm{H}, \mathrm{J}=8.0 \mathrm{~Hz}, \mathrm{~J}=2.0 \mathrm{~Hz}, \mathrm{PyrH}$ ), $7.82(\mathrm{~m}, 12 \mathrm{H}+6 \mathrm{H}, \mathrm{PyrH}+\mathrm{ArH}), 7.98(\mathrm{~d}, 12 \mathrm{H}, \mathrm{J}=8.0 \mathrm{~Hz}, \mathrm{ArH}), 4.37(\mathrm{~m}, 12 \mathrm{H}$,

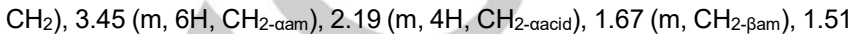

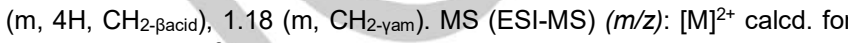
$\left[\mathrm{C}_{102} \mathrm{H}_{98} \mathrm{~N}_{14} \mathrm{O}_{4} \mathrm{Zn}_{2}\right]^{2+}, 856.9$ found 857.0.

\section{General procedure for the competition experiments}

$200 \mu \mathrm{l}(1.0 \mu \mathrm{mol}, 1$ equiv) of a solution $0.005 \mathrm{M}$ of complex $\mathbf{2} \cdot \mathbf{M}$ in DMSO$\mathrm{d}_{6}, 50 \mu \mathrm{l}(0.5 \mu \mathrm{mol}, 0.5$ equiv) of a solution $0.01 \mathrm{M}$ in DMSO-d 6 of dicarboxylic acids $\mathrm{C}_{4}-\mathrm{C}_{14}$ and $125 \mu \mathrm{l}(2.5 \mu \mathrm{mol}, 2.5$ equiv) of a solution 0.02 $\mathrm{M}$ in DMSO- $\mathrm{d}_{6}$ of the desired diamine $3 \mathrm{a}-\mathrm{h}$ were added in a NMR tube. The mixture was left for 24 hours at room temperature and checked via ${ }^{1} \mathrm{H}$ NMR and ESI-MS. In order to override artifacts coming from the ionization method or the MS analysis, the experiments have been carried out using two different instruments (Applied Biosystems ESI-TOF Mariner Biospectrometry Workstation and Agilent Technologies LC/MSD Trap SL AGILENT) which gave comparable results. 


\section{Acknowledgements}

The research was funded by Università di Padova (PRATCPDA153122 and BIRD 2016). Discussion within COST Action CM1304 are acknowledged.

Keywords: supramolecular chemistry $\cdot$ dynamic covalent chemistry $\bullet$ supramolecular cages $\bullet$ TPMA $\cdot$ molecular recognition

[1] a) J. T. A. Jones, T. Hasell, X. Wu, J. Bacsa, K. E. Jelfs, M. Schmidtmann, S. Y. Chong, D. J. Adams, A. Trewin, F. Schiffman, F. Cora, B. Slater, A Steiner, G. M. Day, A. I. Cooper, Nature 2011, 474, 367-371; b) K. Harris D. Fujita, M. Fujita, Chem. Comm. 2013, 49, 6703-6712; c) T. Kusukawa, M. Fujita, Angew. Chem. Int. Ed. 1998, 37, 3142-3144; d) J.-N. Rebilly, B. Colasson, O. Bistri, D. Over, O. Reinaud, Chem. Soc. Rev. 2015, 44 467-489; e) S. H. A. M. Leenders, R. Gramage-Doria, B. de Bruin, J. N. H. Reek, Chem. Soc. Rev. 2015, 44, 433-448; f) S. Fujii, T. Tada, Y Komoto, T. Osuga, T. Murase, M. Fujita, M. Kiguchi, J. Am. Chem. Soc. 2015, 137, 5939-5947; g) J. R. Romero, G. Aragay, P. Ballester, Chem. Sci. 2017, 8, 491-498; h) D. Zhang, J. R. Cochrane, S. Di Pietro, L. Guy, H. Gornitzka, J.-P. Dutasta, A. Martinez, Chem. Eur. J. 2017, 23, 6495 6498; i) D. Zhang, B. Bousquet, J.-C. Mulatier, D. Pitrat, M. Jean, N Vanthuyne, L. Guy, J.-P. Dutasta, A. Martinez, J. Org. Chem. 2017, 82 6082-6088.

[2] a) T. Heinz, D. M. Rudkevich, J. Rebek, Nature 1998, 394, 764-766; b) L. Trembleau, J. Rebek, Science 2003, 301, 1219; c) D. Ajami, J. Rebek, Nat. Chem. 2009, 1, 87-90.

[3] a) S. Mecozzi, J. J. Rebek, Chem. Eur. J. 1998, 4, 1016-1022; b) L. Baldini, P. Ballester, A. Casnati, R. M. Gomila, C. A. Hunter, F. Sansone, R. Ungaro, J. Am. Chem. Soc. 2003, 125, 14181-14189; c) W. M. Bloch, Y. Abe, J. J. Holstein, C. M. Wandtke, B. Dittrich, G. H. Clever, J. Am. Chem. Soc. 2016, 138, 13750-13755. (d) D. J. Cram, Nature 1992, 356, 29-36. (e) D. J. Cram, J. M. Cram, Acc. Chem. Res. 1978, 11, 8-14. (f) D. J. Cram, J. M. Cram, Science 1974, 183, 803-809. (g) D. J. Cram, J. M. Cram Container Molecules and Their Guests, RSC 1997. (h) L. Garel, J.-P. Dutasta, A. Collet, Angew. Chem. Int. Ed.1993, 32, 1169-1171; (i) L. Garel, B. Lozach, J. P. Dutasta, A. Collet, J. Am. Chem. Soc.1993, $115,11652-11653$

[4] a) A. M. Castilla, T. K. Ronson, J. R. Nitschke, J. Am. Chem. Soc. 2016, 138, 2342-2351; b) A. B. Grommet, J. L. Bolliger, C. Browne, J. R. Nitschke, Angew. Chem. Int. Ed. 2015, 54, 15100-15104; c) A. B. Grommet, J. R. Nitschke, J. Am. Chem. Soc. 2017, 139, 2176-2179; d) R. Haag, Angew. Chem. Int. Ed. 2004, 43, 278-282; e) T. Sawada, M. Yoshizawa, S. Sato, M. Fujita, Nat. Chem. 2009, 1, 53-56; f) V. M. Dong, D. Fiedler, B. Carl, R. G. Bergman, K. N. Raymond, J. Am. Chem. Soc. 2006, 128, 14464-14465; g) W. Cullen, M. C. Misuraca, C. A. Hunter, N. H. Williams, M. D. Ward, Nat. Chem. 2016, 8, 231-236; h) Z. Laughrey, B. C. Gibb, Chem. Soc. Rev. 2011, 40, 363-386; i) C. Colomban, G. Szalóki, M. Allain, L. Gómez, S. Goeb, M. Sallé, M. Costas, X. Ribas Chem. Eur. J., 2017, 23, 3016-3022; I) C. Fuertes-Espinosa, C. GarcíaSimón, E. Castro, M. Costas, L. Echegoyen, X. Ribas Chem. Eur. J., 2017, 23, 3553-3557; m) C. García-Simón, M. Costas, X. Ribas Chem. Soc. Rev. 2016, 45, 40-62.

[5] a) J.-M. Lehn, Chem. Eur. J. 1999, 5, 2455-2463; b) P. T. Corbett, J. Leclaire, L. Vial, K. R. West, J.-L. Wietor, J. K. M. Sanders, S. Otto, Chem Rev. 2006, 106, 3652-3711; c) S. J. Rowan, S. J. Cantrill, G. R. L. Cousins, J. K. M. Sanders, J. F. Stoddart, Angew. Chem. Int. Ed. 2002, 41, 898-952.

[6] a) M. Mastalerz, Angew. Chem. Int. Ed. 2010, 49, 5042-5053; b) A. Granzhan, C. Schouwey, T. Riis-Johannessen, R. Scopelliti, K. Severin J. Am. Chem. Soc. 2011, 133, 7106-7115; c) T. Mitra, K. E. Jelfs, M. Schmidtmann, A. Ahmed, S. Y. Chong, D. J. Adams, A. I. Cooper, Nat.
Chem. 2013, 5, 276-281; d) T. K. Ronson, C. Giri, N. Kodiah Beyeh, A Minkkinen, F. Topić, J. J. Holstein, K. Rissanen, J. R. Nitschke, Chem Eur. J. 2013, 19, 3374-3382; e) S. Zarra, D. M. Wood, D. A. Roberts, J. R. Nitschke, Chem. Soc. Rev. 2015, 44, 419-432; f) M. J. Barrell, A. G. Campaña, M. von Delius, E. M. Geertsema, D. A. Leigh, Angew. Chem. Int. Ed. 2011, 50, 285-290

[7] a) J. Mosquera, S. Zarra, J. R. Nitschke, Angew. Chem. Int. Ed. 2014, 53, 1556-1559; b) S. Löffler, J. Lübben, L. Krause, D. Stalke, B. Dittrich G. H. Clever, J. Am. Chem. Soc. 2015, 137, 1060-1063; c) W. Cullen, S. Turega, C. A. Hunter, M. D. Ward, Chem. Sci. 2015, 6, 625-631; d) G. ladevaia, A. E. Stross, A. Neumann, C. A. Hunter, Chem. Sci. 2016, 7, 1760-1767; e) D. Nunez-Villanueva, C. A. Hunter, Chem. Sci. 2017, 8 , 206-213.

[8] a) M. J. Packer, C. Zonta, C. A. Hunter, J. Mag.Res. 2003, 162, 102-112; b) C. A. Hunter, M. C. Misuraca, S. M. Turega, Chem. Sci. 2012, 3, 24622469 .

[9] a) J. Atcher, J. Bujons, I. Alfonso, Chem. Comm. 2017, 53, 4274-4277; b) J. Atcher, A. Moure, J. Bujons, I. Alfonso, Chem. Eur. J. 2015, 21, 6869-6878; c) A. M. Valdivielso, F. Puig-Castellví, J. Atcher, J. Solà, R. Tauler, I. Alfonso, Chem. Eur. J. 2017, 23, 10702-10702; d) M. Ciaccia, I. Tosi, L. Baldini, R. Cacciapaglia, L. Mandolini, S. Di Stefano, C. A. Hunter, Chem. Sci. 2015, 6, 144-151; e) L. You, D. Zha, E. V. Anslyn, Chem. Rev. 2015, 115, 7840-7892; f) D. Zamora-Olivares, T. S. Kaoud K. N. Dalby, E. V. Anslyn, J. Am. Chem. Soc. 2013, 135, 14814-14820 g) Z. Kostereli, R. Scopelliti, K. Severin, Chem. Sci. 2014, 5, 2456-2460; h) T. Takeuchi, S. Matile, Chem. Comm. 2013, 49, 19-29. i) E. Faggi,C. Vicent, S. V. Luis, I. Alfonso, Org. Biomol. Chem. 2015,13, 11721-11731. j) E. Faggi, A. Moure, M. Bolte, C. Vicent, S. V. Luis, I. Alfonso, J. Org. Chem. 2014, 79, 4590-4601.

[10] a) F. A. Scaramuzzo, G. Licini, C. Zonta, Chem. Eur. J. 2013, 19, 16809 16813; b) E. Badetti, K. Wurst, G. Licini, C. Zonta Chem. Eur. J. 2016 22, 6515-6518; c) F. A. Scaramuzzo, E. Badetti, G. Licini, C. Zonta, Eur J. Org. Chem. 2017, 2017, 1438-1442; d) R. Berardozzi, E. Badetti, N. A Carmo dos Santos, K. Wurst, G. Licini, G. Pescitelli, C. Zonta, L. Di Bari, Chem. Comm. 2016, 52, 8428-8431; e) N. A. Carmo dos Santos, E. Badetti, G. Licini, S. Abbate, G. Longhi, C. Zonta, Chirality, DOI: 10.1002/chir.22780.

[11] C. Bravin, E. Badetti, F. A. Scaramuzzo, G. Licini, C. Zonta, J. Am. Chem Soc. 2017, 139, 6456-6460.

[12] G. Zhang, M. Mastalerz, Chem. Soc. Rev. 2014, 43, 1934-1947.

[13] a) S. Turega, W. Cullen, M. Whitehead, C. A. Hunter, M. D. Ward, J. Am. Chem. Soc. 2014, 136, 8475-8483; b) C. G. P. Taylor, W. Cullen, O. M. Collier, M. D. Ward, Chem. Eur. J. 2017, 23, 206-213.

[14] One extra equivalent of diamine has shown to be necessary for cage formation and dicarboxylic acid deprotonation.(See ref. 11).

[15] a) X. Cheng, R. Chen, J. E. Bruce, B. L. Schwartz, G. A. Anderson, S. A. Hofstadler, D. C. Gale, R. D. Smith, J. Gao, G. B. Sigal, M. Mammen, G. M. Whitesides, J. Am. Chem. Soc. 1995, 117, 8859-8860; b) S. R. Wilson, J. Perez, A. Pasternak, J. Am. Chem. Soc. 1993, 115, 1994-1997; c) L. Cera, C. A. Schalley, Chem. Soc. Rev. 2014, 43, 1800-1812; d) Z. Qi, T. Heinrich, S. Moorthy, C. A. Schalley, Chem. Soc. Rev. 2015, 44, 515531; e) M. Kieffer, B. S. Pilgrim, T. K. Ronson, D. A. Roberts, M Aleksanyan, J. R. Nitschke, J. Am. Chem. Soc. 2016, 138, 6813-6821.

[16] a) S. P. Black, D. M. Wood, F. B. Schwarz, T. K. Ronson, J. J. Holstein, A. R. Stefankiewicz, C. A. Schalley, J. K. M. Sanders, J. R. Nitschke, Chem. Sci. 2016, 7, 2614-2620; b) E. Leize, A. Jaffrezic, A. Van Dorsselaer, J. Mass Spectrometry 1996, 31, 537-544; c) P. N. W. Baxter, R. G. Khoury, J.-M. Lehn, G. Baum, D. Fenske, Chem. Eur. J. 2000, 6 , 4140-4148.

[17] M. W. Schneider, I. M. Oppel, M. Mastalerz, Chem. Eur. J. 2012, 18 4156-4160

[18] a) W. C. Isley, S. Zarra, R. K. Carlson, R. A. Bilbeisi, T. K. Ronson, J. R. Nitschke, L. Gagliardi, C. J. Cramer, Phys. Chem. Chem. Phys. 2014, 16, 10620-10628; b) S. Turega, M. Whitehead, B. R. Hall, A. J. H. M. Meijer, C. A. Hunter, M. D. Ward, Inorg. Chem. 2013, 52, 1122-1132. 
[19] a) T. Pintauer, K. Matyjaszewski, Coord. Chem. Rev. 2005, 249, 11551184; b) N. A. Carmo dos Santos, F. Lorandi, E. Badetti, K. Wurst, A. A Isse, A. Gennaro, G. Licini, C. Zonta, Polymer 2017, 128, 169-176.
[20] M. V. Veidis, G. H. Schreiber, T. E. Gough, G. J. Palenik, J. Am. Chem. Soc. 1969, 91, 1859-1860. 
Entry for the Table of Contents (Please choose one layout)

Layout 1:

\section{FULL PAPER}

ESI-MS can be used as rapid method for the determination of binding profiles for linear saturated dicarboxylic acids within a series of different self-assembled supramolecular cages.

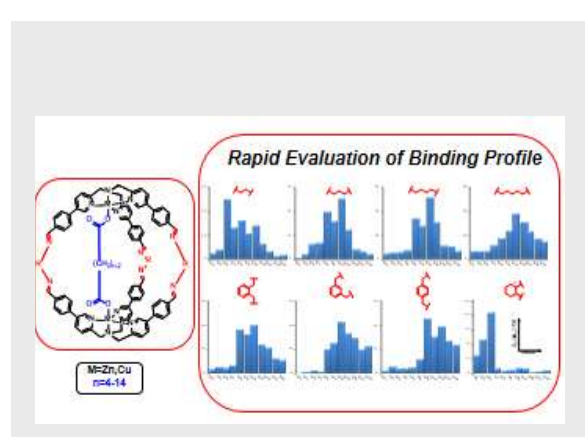

C. Bravin, E. Badetti, R. Puttreddy, F. Pan, K. Rissanen, G. Licini, and C. Zonta*

Page No. - Page No.

Binding Profiles of Self-Assembled Supramolecular Cages from ESI-MS Based Methodology

Layout 2:

\section{FULL PAPER}

((Insert TOC Graphic here; max. width: $11.5 \mathrm{~cm}$; max. height: $2.5 \mathrm{~cm})$ )
Author(s), Corresponding Author(s)*

Page No. - Page No.

Title

Text for Table of Contents 